\title{
The acute phase protein orosomucoid 1 is upregulated in early lactation but does not trigger appetite-suppressing STAT3 signaling via the leptin receptor
}

\author{
M. M. McGuckin, ${ }^{1}$ S. L. Giesy, ${ }^{1}$ A. N. Davis, ${ }^{1}$ M. A. Abyeta, ${ }^{2}$ E. A. Horst, ${ }^{2}$ S. Saed Samii, ${ }^{3}$ Y. Zang, ${ }^{3}$ W. R. Butler, ${ }^{1}$ \\ L. H. Baumgard, ${ }^{2}$ J. W. McFadden, ${ }^{1}$ and Y. R. Boisclair ${ }^{1 *}$ \\ ${ }^{1}$ Department of Animal Science, Cornell University, Ithaca, NY 14853 \\ ${ }^{2}$ Department of Animal Science, lowa State University, Ames 50011 \\ ${ }^{3}$ Division of Animal and Nutritional Sciences, West Virginia University, Morgantown 26505
}

\begin{abstract}
Dairy cows consume inadequate amounts of feed in early lactation and during conditions and diseases such as excessive fatness, heat stress, and infectious diseases. Affected cows often experience increases in plasma concentrations of acute phase proteins consistent with the negative effect of inflammation on appetite. The acute phase protein orosomucoid 1 (ORM1), also known as alpha-1-acid glycoprotein, was recently reported to reduce appetite in the mouse through its ability to bind the full-length leptin receptor $(\mathrm{Ob}-\mathrm{Rb})$ and activate appetite-suppressing signal transducer and activator of transcription 3 (STAT3) signaling. These observations raise the possibility that ORM1 exerts appetitesuppressing effects in dairy cattle during periods of increased inflammatory tone. The applicability of this model was assessed in 2 ways. First, we asked whether ORM1 is regulated during periods of inadequate appetite such as the transition from late pregnancy to early lactation and periods of increased inflammatory tone. Plasma ORM1 was invariant in late pregnancy but increased 2.5-fold between parturition and $\mathrm{d} 7$ of lactation. Gene expression studies showed that liver was the major source of this elevation with little contribution by adipose tissue or mammary gland. Additional studies showed that plasma ORM1 was not increased further by excessive fatness or by reproductive dysfunction in early lactation and was completely unresponsive to inflammatory stimuli such as heat stress or intravascular administration of the endotoxin lipopolysaccharide during established lactation. Second, we tested the ability of ORM1 to trigger STAT3 signaling through Ob-Rb using Chinese hamster ovary K1 (CHO-K1) cells transfected with a STAT3 expression plasmid. In
\end{abstract}

Received December 19, 2019.

Accepted January 9, 2020.

*Corresponding author: yrb1@cornell.edu this configuration, CHO-K1 cells did not express Ob$\mathrm{Rb}$ and were incapable of leptin-induced STAT3 phosphorylation. Leptin responsiveness was conferred by co-transfecting with bovine Ob-Rb, with leptin causing increases of 5.7-fold in STAT3 phosphorylation and 2.1fold in the expression of the STAT3-dependent gene, SOCS3. In contrast, neither bovine or human ORM1 triggered STAT3 phosphorylation irrespective of dose and period of incubation tested. In summary, bovine ORM1 is not increased during periods of increased inflammatory tone except in early lactation and is incapable of Ob-Rb-dependent STAT3 signaling. Overall, these data are inconsistent with ORM1 mediating the appetite-suppressing effects of inflammation in cattle through Ob-Rb.

Key words: alpha-1-acid glycoprotein, heat stress, inflammation, transition dairy cow

\section{INTRODUCTION}

The transition from late pregnancy (LP) to early lactation (EL) represents the most challenging period of the life cycle of dairy cows (Drackley, 1999; Roche et al., 2013). In the span of a few days, dairy cows experience parturition, uterine involution, and onset of copious milk secretion all in the context of a rapidly growing nutritional deficit. This challenge is exacerbated further by conditions and diseases suppressing voluntary feed intake such as excessive fatness, heat stress, ketosis, and metritis (Roche et al., 2013; Eckel and Ametaj, 2016). Notably, the plasma concentrations of the inflammatory biomarkers haptoglobin (HP), serum amyloid A (SAA), or LPS binding protein (LBP) are elevated during these conditions. Growing evidence has linked this elevation in inflammatory tone to vascular entry of endotoxins occurring as a consequence of loss of integrity of the intestinal gut barrier or from bacterial infections (Baumgard and Rhoads, 2013; Eckel and Ametaj, 2016). 
Several studies have implicated tumor necrosis factor $\alpha$ and other pro-inflammatory cytokines in the appetite suppressing effects of inflammation (Dantzer et al., 2008) but do not exclude the possibility of additional proteins acting directly on neural networks engaged in the regulation of energy metabolism. An intriguing report, in this context, is the observation that orosomucoid 1 (ORM1) reduced appetite in the mouse (Sun et al., 2016). Orosomucoid 1 is also known as alpha-1-acid glycoprotein and is recognized in most species as an endotoxin-activated acute phase protein (APP; Ceciliani et al., 2012). Sun et al. (2016) reported that ORM1 is also capable of binding to the fully functional leptin receptor (Ob-Rb) and triggers activation of signal transducer and activator of transcription 3 (STAT3) signaling. Because leptin-dependent STAT3 activation in neuronal cells is both necessary and sufficient to suppress appetite (Bates et al., 2003; Pan et al., 2019), these observations suggest that increased ORM1 could contribute to the reduced appetite observed under conditions associated with increased inflammatory tone.

We are unaware of any study in dairy cattle focusing on the regulation of plasma ORM1 when appetite is insufficient or inadequate as a consequence of stage of lactation, fatness, heat stress, and increased inflammatory tone. In this report, we investigated 2 requirements that must be met for bovine ORM1 to serve as a physiological regulator of appetite under these conditions. Specifically, we asked first whether plasma ORM1 was increased during any of these conditions, and second, whether ORM1 was able to activate bovine Ob-Rbdependent STAT3 signaling. Our results show that ORM1 increases after parturition but is not regulated by conditions associated with increased inflammatory tone such as heat stress or i.v. endotoxin administration. Furthermore, we showed that ORM1 is unable to activate STAT3 signaling through bovine Ob-Rb.

\section{MATERIALS AND METHODS}

\section{Animals and Design}

Plasma samples were analyzed from previous experiments performed with Holstein dairy cattle (Thorn et al., 2007; Soberon et al., 2011; Cheong et al., 2017; Davis et al., 2019; Horst et al., 2019; Saed Samii et al., 2019; Zang et al., 2019). Studies were conducted at West Virginia University, Iowa State University, and Cornell University with the guidance and approval of the local Institutional Animal Care and Use Committee. Unless specifically noted, animals used were multiparous dairy cows fed unlimited amounts of TMR formulated for LP (1.43-1.44 Mcal of $\mathrm{NE}_{\mathrm{L}}$ and $122-154 \mathrm{~g}$ of $\mathrm{CP}$ per $\mathrm{kg}$ of
$\mathrm{DM})$ or lactation (1.54-1.70 Mcal of $\mathrm{NE}_{\mathrm{L}}$ and 155-169 $\mathrm{g}$ of $\mathrm{CP}$ per $\mathrm{kg}$ of $\mathrm{DM}$ ) and displayed no clinical signs of disease. Intake was recorded on an individual basis, and milking was performed twice daily except for thrice daily in the study of Cheong et al. (2017). Blood was collected by coccygeal venipuncture into tubes containing K-EDTA or heparin and processed to plasma by centrifugation. When taken, tissues were obtained after local anesthesia using biopsy tools for liver and mammary gland and dissection for tail head adipose tissue (Soberon et al., 2011; Davis et al., 2019). All tissues were snap frozen in liquid nitrogen and stored at $-80^{\circ} \mathrm{C}$ until subsequent RNA analysis. Design and details specific to each experiment were as follows.

\section{ORM1 Regulation During the Transition Period}

The profile of plasma ORM1 between LP and EL was assessed in cows receiving the unsupplemented diet in a study of Zang et al. (2019) investigating the effect of methyl donor supplementation. Plasma samples were collected from 6 cows on $\mathrm{d}-21,-14,-7,-3,0,+3,+$ $7,+10,+14$, and +21 relative to parturition.

Effects of the periparturient period on ORM1 mRNA abundance were examined in 2 additional studies. Changes in ORM1 mRNA abundance in liver and adipose tissue were assessed in 6 lean cows with an average BCS of $2.9 \pm 0.1$ on $\mathrm{d}-28$ relative to parturition (Davis et al., 2019). Orosomucoid 1 concentration was measured on plasma samples obtained on $\mathrm{d}-12,+10$, and +12 relative to parturition, whereas ORM1 mRNA abundance was measured on liver and tail-head adipose tissue obtained on $d-12$ and $d+10$. The study of Soberon et al. (2011) was used to assess the possibility of ORM1 production by the mammary gland. Orosomucoid 1 mRNA was analyzed in mammary biopsies collected from 7 cows on the day of parturition and on d 21 of lactation.

A final study was used to survey ORM1 mRNA abundance in bovine tissues (Thorn et al., 2007). The study involved 4 heifers growing at the average daily rate of $650 \mathrm{~g} / \mathrm{d}$ and killed at $6 \mathrm{mo}$ of age by stunning with a captive bolt and exsanguination. Tissues collected were gastrocnemius muscle, heart, liver, lung, spleen, adrenal gland, kidney (medulla and cortex), uterine epithelium, pituitary gland, ovary, and hypothalamus.

\section{ORM1 Regulation During Conditions Associated with Reduced Appetite}

The effect of excessive fatness was examined using the study of Saed Samii et al. (2019). Orosomucoid 1 concentration was assayed on plasma samples collected 
on $\mathrm{d}-14,+2$, and +7 relative to parturition in cows classified on $\mathrm{d}-28$ as either lean $(\mathrm{BCS}=2.9 \pm 0.2 \mathrm{n}$ $=7)$ or fat $(\mathrm{BCS}=4.0 \pm 0.2, \mathrm{n}=7)$.

The effect of heat stress on ORM1 was evaluated in mid-lactating dairy cows $(683 \pm 14 \mathrm{~kg}$ of $\mathrm{BW} ; 138$ \pm 6 DIM; parity $2.4 \pm 0.3$ ). Cows were kept under thermoneutral conditions and fed ad libitum during a baseline period of $4 \mathrm{~d}$ followed immediately by a treatment period of $7 \mathrm{~d}$ when cows were either subjected to heat stress and fed ad libitum (heat stress, $\mathrm{n}=7$ ) or kept at thermoneutrality (control, $\mathrm{n}=7$ ). The heat stress treatment was administered via the electric heat blanket procedure exactly as described by Al-Qaisi et al. (2019). Plasma ORM1 was analyzed on samples obtained on the last day of the basal period and on $\mathrm{d} 7$ of the treatment period.

The effect of postparturient inflammation was assessed using the study of Cheong et al. (2017) where transition cows were retrospectively classified on the basis of the fate of the first dominant follicle as ovulatory or nonovulatory ( $\mathrm{n}=10$ per group). Plasma ORM1 was measured on $\mathrm{d}+3$ relative to parturition when the inflammatory marker HP was increased in nonovulatory cows and on $\mathrm{d}-16$ and +15 when it did not differ between groups.

The effect of endotoxin was examined using the study by Horst et al. (2019) involving late lactating dairy cows (273 \pm 35 DIM). The study consisted of a baseline period of $5 \mathrm{~d}$ followed by the treatment period of $16 \mathrm{~h}$ when all cows were feed deprived and infused at the rate of $200 \mathrm{~mL} / \mathrm{h}$ with a $20 \%$ intralipid solution (Frasenius Kabi, Deerfield, IL). Treatments were administered at time 0 of the treatment period and were an i.v. bolus of either saline or LPS ( $n=5$ per group). The LPS was prepared from Escherichia coli O55:B5 (lot \#057M4013V, Sigma-Aldrich, St. Louis, MO) and was administered at a dose of $0.375 \mu \mathrm{g} / \mathrm{kg}$ BW. Samples collected included plasma at $0,+4,+8,+12$, and +16 $\mathrm{h}$ relative to bolus administration and liver biopsies at $+16 \mathrm{~h}$.

\section{Cell-Based Assays of Leptin and ORM1 Signaling}

Stock cultures of Chinese hamster ovary K1 (CHOK1) cell line were obtained from ATCC (ATCC CCL61, Manassas, VA) and grown at $37^{\circ} \mathrm{C}$ with $5 \% \mathrm{CO}_{2}$ in complete F-12K growth medium (Gibco, Waltham, MA) supplemented with $10 \%$ fetal calf serum, $50 \mathrm{U} /$ $\mathrm{mL}$ penicillin, $50 \mathrm{U} / \mathrm{mL}$ streptomycin, and $2 \mathrm{mM}$ glutamine. For experiments, CHO-K1 were grown to $\sim 70 \%$ confluence in 12 -well plates and transfected with $0.5 \mu \mathrm{g} /$ well of STAT3 expression plasmid pRc/CMVSTAT3 (Zhong et al., 1994) in the absence or presence of $3 \mu \mathrm{g} /$ well of pcDNA-bLEPR. The pcDNA-bLEPR was constructed into the core plasmid pCDNA 3.1 by inserting the bovine cDNA clone A90113 (GenScript, Piscataway, NJ). Sequencing of pcDNA-bLEPR confirmed identity of the inserted cDNA with the coding sequence of bovine Ob-Rb (Refseq XM_010803430.1) and insertion at the appropriate sites into pCDNA 3.1. Transfection was performed for $12 \mathrm{~h}$ in F-12K growth medium supplemented with $2 \%$ fetal calf serum and 2 $\mathrm{m} M$ glutamine with FuGene reagent (Promega, Madison, WI) at the ratio of $3 \mu \mathrm{L} / \mu \mathrm{g}$ DNA. After a $24-\mathrm{h}$ recovery period in complete $\mathrm{F}-12 \mathrm{~K}$ medium, cells were incubated for $16 \mathrm{~h}$ in serum-free F-12K medium. Media were then changed to serum-free F-12K medium supplemented with rat IL-6 (PeproTech Inc., Rocky Hill, NJ), bovine leptin (Protein Laboratories, Rehovot, Israel), or human or mouse leptin (National Institute of Diabetes, and Digestive and Kidney Diseases, Bethesda, MA) or bovine or human ORM1 (Sigma-Aldrich) at concentrations and times indicated in the figure legends.

\section{Analysis of Plasma ORM1 and SAA}

Plasma ORM1 concentration was measured with a bovine Alpha 1-Acid Glycoprotein ELISA exactly as recommended by the supplier (Immunology Consultant Laboratory, Portland, OR). The ORM1 assay was linear in serially diluted samples and recovery of added bovine ORM1 in LP and EL plasma was 93.2 and $105.1 \%$, respectively $(\mathrm{n}=3)$. Plasma SAA concentrations were measured with a commercially available ELISA (Tridelta Development Ltd., Kildare, Ireland) as we previously described (Kvidera et al., 2017). The inter- and intraassay coefficients of variation for the ORM1 and SAA assays averaged 15.5 and $4.6 \%$ and 8.2 and $4.9 \%$, respectively.

\section{RNA Extraction and Analysis of Gene Expression}

Tissue and cell samples were lysed with Qiazol (Qiagen, Valencia, CA) followed by purification of total RNA using RNeasy Mini columns and on-column RNase-free DNase treatment (Qiagen). Quality of RNA was determined using the RNA Nano Lab Chip kit and bioanalyzer (Agilent, Palo Alto, CA) with all samples having an RNA integrity number $>7.0$. Reverse transcription reactions were performed with $1 \mu \mathrm{g}$ of total RNA in a total $20-\mu \mathrm{L}$ volume with the high-capacity cDNA reverse transcription kit and RNase inhibitor (Applied Biosystems, Foster City, CA). Gene expression was analyzed by quantitative real-time PCR (qPCR) using Power SYBR Green Master Mix (Applied Biosystems). Real-time PCR assays were performed in 
duplicate with a total $25 \mu \mathrm{L}$ reaction volume containing $500 \mathrm{n} M$ concentration of each primer and reversetranscribed mRNA (25 ng except $2.5 \mathrm{ng}$ for the internal standard gene $18 \mathrm{~S}$ ). The sequences of all primers used are given in Supplemental Table S1 (https://doi.org/10 .3168/jds.2019-18094). Primer pairs were designed using Primer-BLAST software (http://www.ncbi.nlm.nih .gov/tools/primer-blast/). Each member of a primer pair was located in adjoining exons of the target gene and shown by BLAST analysis to anneal exclusively to the target sequence. Amplification with each primer pair yielded a single product by melting curve analysis with efficiencies ranging from 0.87 to 1.06 . Data were analyzed using a relative standard curve based on a serial 2-fold dilution of pooled cDNA prepared from liver or CHO-K1 cells. Data were normalized to appropriate invariant genes $[\beta-2$ microglobulin $(B 2 M)$ for CHO-K1 cells; geometric mean of B2M, $18 \mathrm{~S}$ ribosomal RNA (18S), and TATA-box binding protein $(T B P)$ for liver and adipose; geometric mean of $18 S, T B P$, and mitochondrial ribosomal protein L39 (MRPL39) for the tissue survey].

\section{Western Blotting of Cell Lysates}

Cells were lysed in ice-cold lysis buffer (10 $\mathrm{m} M$ Tris, $\mathrm{pH}$ 7.5, $10 \mathrm{~mL} / \mathrm{L}$ of Triton X-100, $150 \mathrm{~m} M \mathrm{NaCl}, 1$ $\mathrm{m} M$ EGTA, Halt protease and phosphatase inhibitor cocktails (Thermo Fisher Scientific, Waltham, MA) and clarified by centrifugation $(10,000 \times g$ for $15 \mathrm{~min}$ at $4^{\circ} \mathrm{C}$ ). Protein concentrations were measured with the BCA Protein Assay Kit (Pierce, Rockford, IL). Fixed amounts of total protein $(25 \mu \mathrm{g})$ were separated on $10 \%$ SDS-polyacrylamide gels under reducing conditions and electroblotted onto nitrocellulose membranes (GE Healthcare, Munich, Germany). Membranes were incubated in blocking solution $(50 \mathrm{~m} M$ Tris, $\mathrm{pH} 7.4$, $200 \mathrm{mM} \mathrm{NaCl}, 0.1 \%$ Tween $20,5 \%$ nonfat dry skim milk) for $1 \mathrm{~h}$ at room temperature followed by overnight incubation at $4^{\circ} \mathrm{C}$ with a $1: 1,000$ dilution of antibody against signal transducer and activator of transcription-3 phosphorylated on tyrosine 705 (pSTAT3, Cell Signaling, Danvers, MA). Signals were developed using a 1:20,000 dilution of IRDye goat anti-rabbit antibody (LI-COR Biosciences, Lincoln, NE) in 5\% nonfat dried skim milk and detected using the $800 \mathrm{~nm}$ channel with the LI-COR Odyssey imaging system (LI-COR Biotechnology). The membranes were stripped using re-blot (Thermo Fisher Scientific) and re-probed with a 1:1,000 dilution of antibody against total STAT3 (Santa Cruz Biotechnology, Santa Cruz, CA) and $\beta$-actin (Cell Signaling). Fluorescent signals were quantified using Image Studio Lite (LI-COR Biosciences).

\section{Statistical Analysis}

Data were analyzed using the fit model procedure of JMP Pro 14 statistical software (SAS Institute Inc., Cary, NC). The plasma ORM1 profile was analyzed using a mixed model with the time relative to parturition (Time) as a fixed effect and cow as a random effect. Plasma ORM1 at different time points was compared by pairwise comparisons with Tukey adjustment. For the analysis of plasma ORM1 in the other experiments involving LP and EL, this model was expanded to include a second fixed factor if present (i.e., Fatness or Ovulation status) as well as its interaction with Time. These additional experiments involved a single time point in LP and 2 time points in EL. Accordingly, when the effect of Time was significant, variation was partitioned into 2 orthogonal contrasts: (1) state (single time point in LP vs. the 2 time points in EL) and (2) lactation (first vs. second time point in EL). Expression data in liver, adipose tissue, and mammary gland were analyzed using a mixed effects model accounting for physiological state (either d -12 vs. +10 or d 0 vs. +21 ) as a fixed effect and cow as a random effect. Data from the heat stress study were analyzed using a mixed model with treatment (Control or Heat Stress), Time $(\mathrm{d}-1$ and +7$)$, and their interaction as fixed effects and cow as the random effect. The study of the effect of the endotoxin LPS was analyzed using a mixed model with treatment (Saline or LPS), time relative to bolus, and their interaction (LPS $\times$ Time) as fixed effects and cow as the random effect. Data from cell experiments were analyzed using treatment (Control, Leptin, or ORM1) as the fixed effect. Statistical significance and tendency were set at $P<0.05$ and at $P<0.10$, respectively.

\section{RESULTS}

\section{Plasma ORM1 During the Transition Period}

We determined the plasma ORM1 profile in transition dairy cows by assaying samples obtained between $\mathrm{d}-21$ and +21 relative to parturition (Zang et al., 2019). Plasma ORM1 varied little in LP, rose linearly between parturition and $\mathrm{d}+7$, and reached plateau concentration between $d+7$ and +21 (Figure 1). Average plasma ORM1 was 2.3-fold higher in EL than in LP (615 vs. $272 \mu \mathrm{g} / \mathrm{mL}$, Time, $P<0.001$ ). Accordingly, plasma ORM1 increases dynamically after parturition when voluntary intake is insufficient to cover nutritional requirements.

To determine whether liver production accounted for increased plasma ORM1 in EL, we used a second transition cow study where liver and adipose tissue biopsies 
were collected on $\mathrm{d}-12$ and +10 relative to parturition (Davis et al., 2019). In this study, plasma ORM1 doubled between LP and EL (Figure 2A, state, $P=$ 0.006 ) and was associated with a 1.9 -fold increase in liver mRNA abundance (Figure 2B, $P=0.06$ ). Plasma ORM1 concentrations over this period were positively correlated with hepatic ORM1 expression (Figure 2C, $P=0.004)$. In contrast, ORM1 expression in adipose tissue did not vary between LP and EL and was unrelated to plasma ORM1 (Figure 2D and results not shown).

The possibility of significant ORM1 expression in the mammary gland was examined in mammary biopsies taken from a separate group of cows at parturition and on $d+21$ of lactation (Soberon et al., 2011). Mammary ORM1 expression did not differ between parturition and $\mathrm{d}+21$ of lactation and was only $0.012 \%$ of liver expression in LP (Figure 3A). Finally, the possibility of high ORM1 production outside of liver was assessed by $\mathrm{qPCR}$ in 11 other tissues from dairy heifers (Figure 3B). The ORM1 cycle threshold number was 30 or higher in all tissues indicating low expression, except in liver where mRNA abundance was $>10,000$-fold higher than that of any other tissue. Collectively, these data indicate that liver is the major site of ORM1 expression and accounts for the elevation of plasma ORM1 in EL.

\section{Plasma ORM1 During Conditions Associated with Reduced Appetite}

Conditions known to reduce voluntary feed intake in lactating dairy cows include excessive fatness, heat stress, and increased inflammatory tone. To determine whether excessive fatness increases plasma ORM1, we

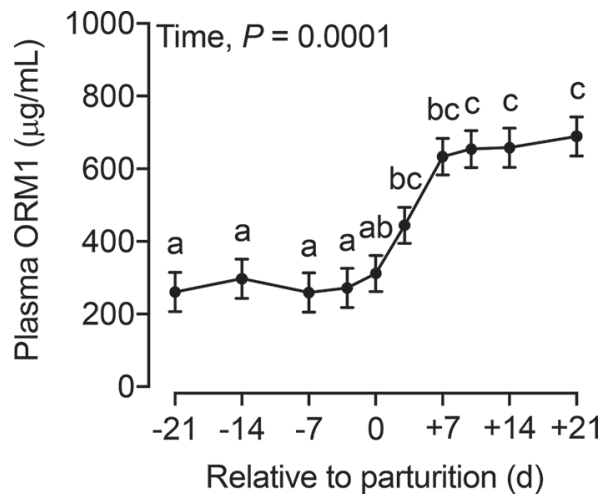

Figure 1. Plasma orosomucoid 1 (ORM1) increases during the transition period in dairy cows. Plasma samples were collected from multiparous dairy cows during late pregnancy and early lactation and were analyzed for ORM1 concentration with a bovine ORM1 ELISA. Each time point represents the LSM \pm SE of 6 cows. The significant effect of Time is reported, and time points with different letters are significantly different at $P<0.05$.
A

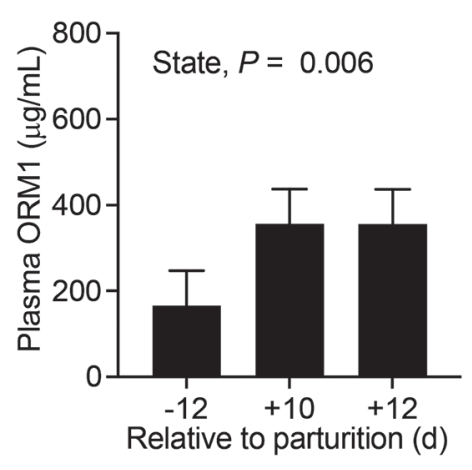

B

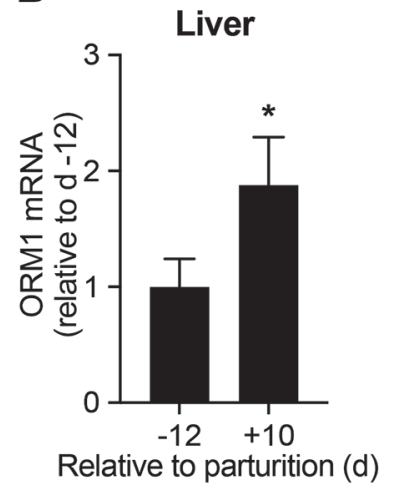

C

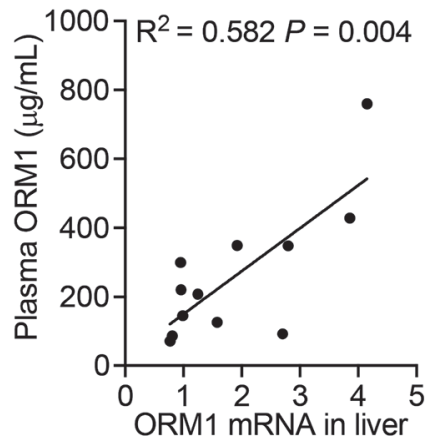

Figure 2. Plasma orosomucoid 1 (ORM1) and ORM1 mRNA abundance in transition dairy cows. (A) Plasma samples were collected from multiparous dairy cows during late pregnancy (d -12) and early lactation $(\mathrm{d}+10$ and +12$)$ and were analyzed for ORM1 concentration with a bovine ORM1 ELISA. Each bar represents the $\mathrm{LSM} \pm \mathrm{SE}$ of 6 cows. The significant effect of physiological State is reported. (B) Total RNA was isolated from liver biopsies obtained in late pregnancy $(\mathrm{d}-12)$ and early lactation $(\mathrm{d}+10)$ and analyzed for ORM1 mRNA abundance. Each bar represents the LSM \pm SE of 6 cows. ${ }^{*} P=0.06$. (C) Correlation between plasma ORM1 concentration and $O R M 1 \mathrm{mRNA}$ abundance in liver during late pregnancy and early lactation. (D) Total RNA was isolated from adipose tissue biopsies obtained in late pregnancy $(\mathrm{d}-12)$ and early lactation $(\mathrm{d}+10)$ and analyzed for ORM1 mRNA abundance. Each bar represents the $\mathrm{LSM} \pm \mathrm{SE}$ of 6 cows.

studied lean and fat cows on $\mathrm{d}-14,+2$, and +7 relative to parturition (Saed Samii et al., 2019). Fat cows had lower voluntary feed intake than lean cows between d 0 and +4 of lactation (11.15 vs $17.77 \mathrm{~kg}$ of DM/d, $P<0.05$ ). Plasma ORM1 was increased in EL (Figure $4 \mathrm{~A}$, state, $P=0.004)$, but excessive fatness did not exacerbate this increase (Fatness, $P=0.84$ and Fatness $\times$ Time, $P=0.50$.

Plasma ORM1 was measured in an experiment where cows were either heat stressed and fed ad libitum (Heat Stress) or kept under thermoneutral conditions (Control). Plasma ORM1 was measured the day before and after $7 \mathrm{~d}$ of heat stress when voluntary feed intake was 
A

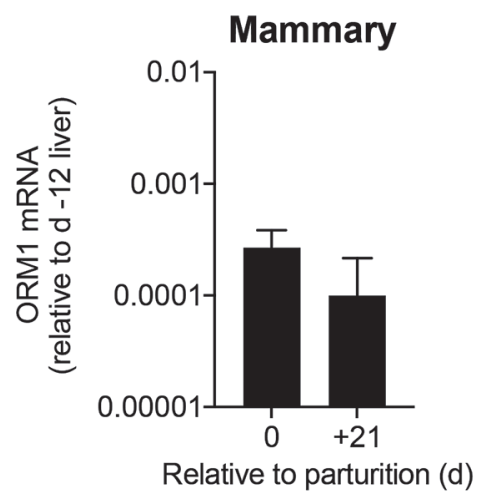

B

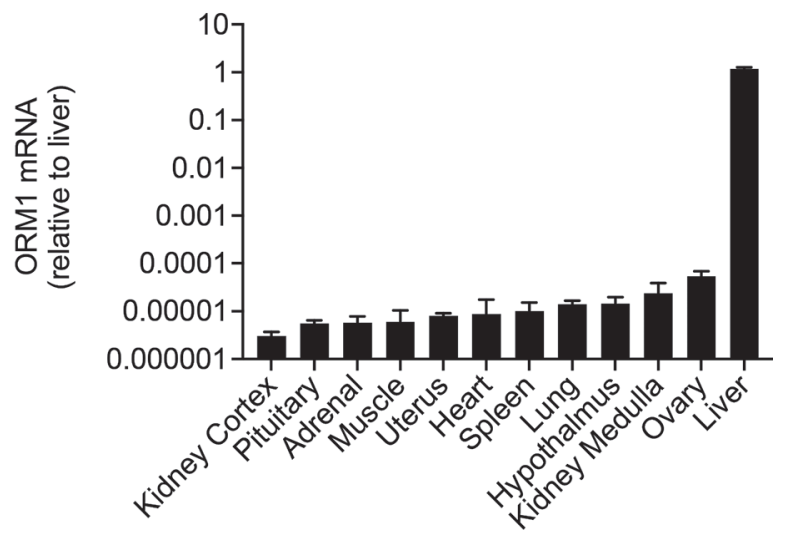

Figure 3. Orosomucoid 1 (ORM1) mRNA abundance in the mammary gland and other tissues. (A) Total RNA was isolated from mammary biopsies obtained from multiparous cows at parturition $(\mathrm{d} 0)$ and early lactation $(\mathrm{d}+21)$ and analyzed for ORM1 mRNA abundance. Expression is relative to d -12 liver shown in Figure 2B. Each bar represents the LSM \pm SE of 6 cows. (B) Total RNA was isolated from tissues collected at slaughter from dairy heifers and analyzed for ORM1 mRNA abundance. Each bar represents the LSM \pm SE of 4 heifers.

reduced by $34 \%$ relative to the pre-treatment period ( $P$ $<0.01$ ). We did not detect Heat Stress, Time, or Heat Stress $\times$ Time effects, indicating that heat stress did not affect plasma ORM1 (Figure 4B).

To assess whether ORM1 is upregulated when inflammatory tone is increased, we measured plasma ORM1 on $\mathrm{d}-16,+3$, and +15 relative to parturition in cows failing to ovulate and having lower appetite in EL (Cheong et al., 2016, 2017). Nonovulatory cows had higher plasma HP than ovulatory cows on $d+3$ of lactation (nonovulatory vs. ovulatory cows, 614 vs. 239 $\mu \mathrm{g} / \mathrm{mL}, P=0.0042)$. As shown in Figure $4 \mathrm{C}$, plasma
ORM1 increased 2.5-fold between LP and EL (State, $P$ $=0.0002)$ but was not increased further on $\mathrm{d}+3$ in the nonovulatory cows (Ovulation, $P=0.93$ and Ovulation $\times$ Time, $P=0.61)$.

The discrepancy between the profile of ORM1 and HP in the previous experiment raised the possibility that endotoxins do not drive ORM1 production in lactating dairy cows. To test this directly, we compared levels of ORM1, SAA, and HP in dairy cows during the 16-h period following i.v. bolus administration of either saline or LPS (Horst et al., 2019). Plasma SAA varied little in saline-treated cows but increased from
A

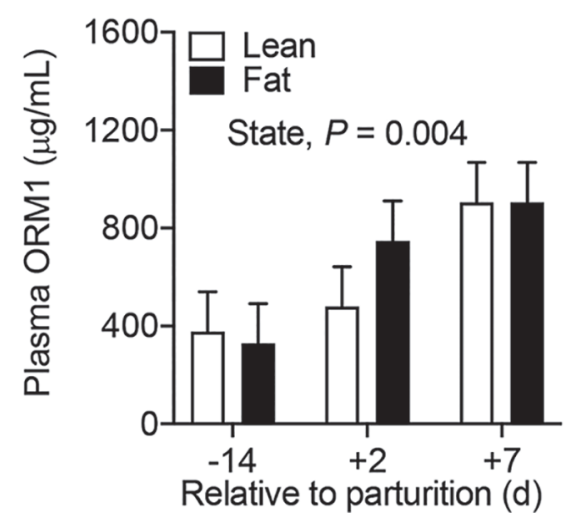

B

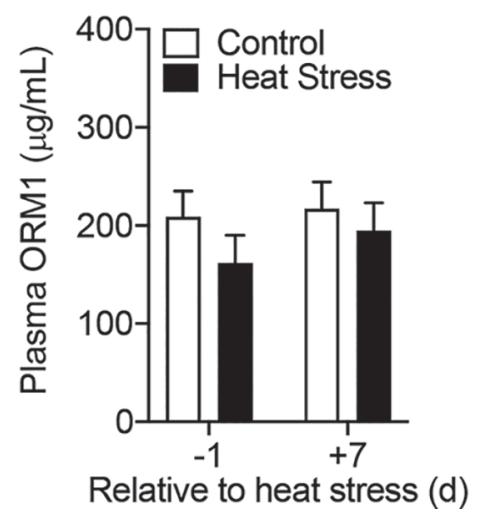

C

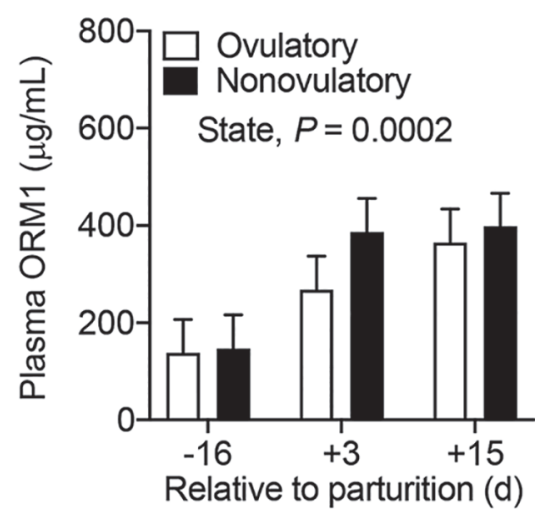

Figure 4. Plasma orosomucoid 1 (ORM1) concentration during conditions associated with reduced voluntary feed intake. Plasma samples were collected from multiparous dairy cows and were analyzed for ORM1 concentration with a bovine ORM1 ELISA. (A) Lean and fat cows were studied in late pregnancy $(\mathrm{d}-14)$ and early lactation $(\mathrm{d}+2$ and +7$)$. Each bar represents the LSM $\pm \mathrm{SE}$ of 7 cows. (B) Mid-lactation cows were studied before treatment $(\mathrm{d}-1)$ or on $\mathrm{d} 7(\mathrm{~d}+7)$ of a period of heat stress (Heat Stress) or under thermoneutral conditions $(\mathrm{Control})$. Each bar represents the LSM $\pm \mathrm{SE}$ of 7 cows. (C) Cows that ovulated (Ovulatory) or did not ovulate (Nonovulatory) the first dominant follicle after parturition were studied in late pregnancy $(\mathrm{d}-16)$ and in early lactation $(\mathrm{d}+3$ and +15$)$. Each bar represents the LSM \pm SE of 10 cows. The significant effect of physiological state (State) is reported. 
A

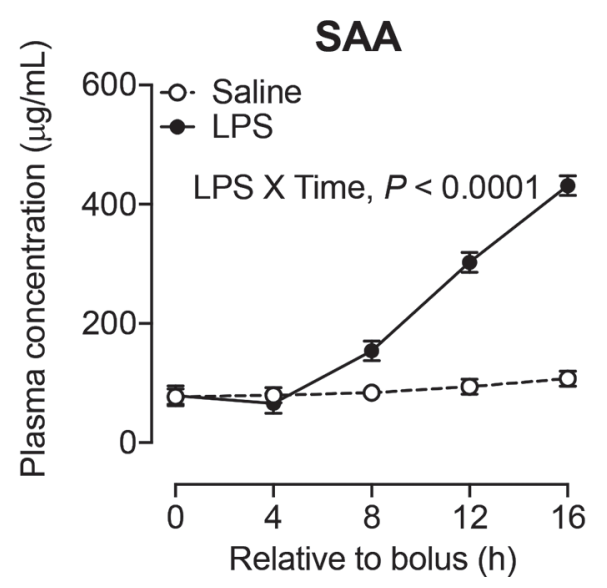

B

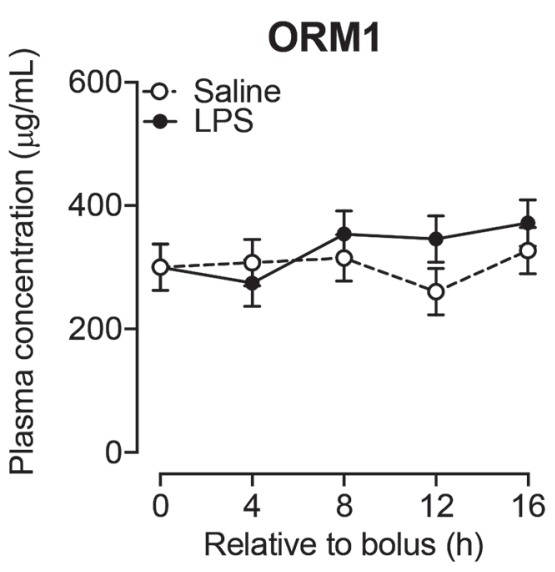

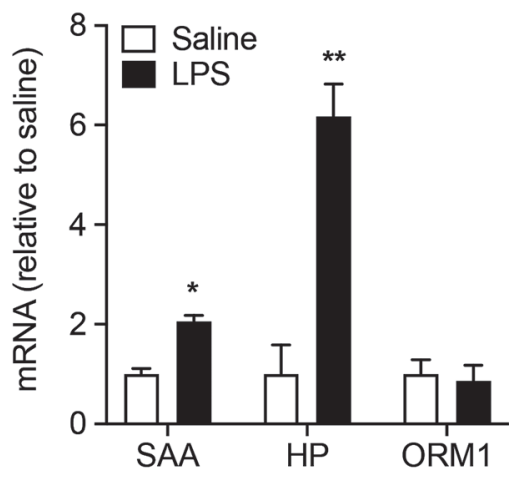

Figure 5. Production indices of serum amyloid-A (SAA), haptoglobin (HP), and orosomucoid 1 (ORM1) following LPS administration. Multiparous dairy cows were feed deprived and infused with an intralipid solution at time 0 followed immediately by an i.v. bolus of saline (3 $\mathrm{mL})$ or LPS $(0.375 \mu \mathrm{g} / \mathrm{kg})$. (A) The concentrations of SAA and ORM1 were measured in plasma samples collected over the $16 \mathrm{~h}$ following i.v. bolus. Each time point represents the LSM \pm SE for 5 cows. The significant effect of the interaction between LPS and time (LPS $\times$ Time) is reported. (B) Total RNA was isolated from liver biopsies collected $16 \mathrm{~h}$ after bolus administration and analyzed for SAA, HP, and ORM1 mRNA abundance. Each bar represents the LSM $\pm \mathrm{SE}$ of 5 cows. ${ }^{*} P=0.0004 ;{ }^{*} P=0.0006$.

78.7 to $431.2 \mu \mathrm{g} / \mathrm{mL}$ over the last $8 \mathrm{~h}$ of the observation period in LPS-treated cows (Figure 5A, $P<0.0001$ ); this increase was associated with increased hepatic expression of both $S A A$ and $H P$ (Figure 5B, $P=0.0004$ and 0.0006 , respectively). In contrast, neither plasma ORM1 nor ORM1 hepatic expression differed between the saline and LPS groups (Figure 5A and 5B; $P=$ 0.3 and 0.8 , respectively). Overall, these data do not support a role for ORM1 in mediating the appetitesuppressing effect of excessive fatness, heat stress, or increased inflammatory tone.

\section{ORM1 Does Not Activate STAT3 Signaling in Cells Expressing the Bovine Ob-Rb}

Orosomucoid 1 has been suggested to reduce feed intake by binding Ob-Rb followed by activation of STAT3 signaling (Sun et al., 2016). To test if this model applies to cattle, we used CHO-K1 cells overexpressing STAT3 in the presence or absence of bovine Ob-Rb. First, CHO-K1 cells overexpressing only STAT3 were incubated for 15 min with either saline solution or 100 $\mathrm{ng} / \mathrm{mL}$ of IL-6 or bovine leptin. Cell lysates were analyzed by western immunoblotting for the presence of STAT3 phosphorylated on tyrosine 705 (Figure 6A). Interleukin-6 caused a robust increase in STAT3 phosphorylation whereas bovine leptin had no visible effect; a similar lack of STAT3 phosphorylation was seen when cells were incubated with $100 \mathrm{ng} / \mathrm{mL}$ of human and murine leptin (results not shown). Consistent with the lack of response to leptin, expression of endogenous Ob$\mathrm{Rb}$ was undetectable in these cells by qPCR.
Next, we used CHO-K1 cells overexpressing both STAT3 and the bovine Ob-Rb. The bovine Ob-Rb was expressed at a high level as indicated by detection of its mRNA at the cycle threshold number of $\sim 15$ by qPCR. Incubation of these cells for $15 \mathrm{~min}$ with $100 \mathrm{ng} / \mathrm{mL}$ of bovine leptin caused a 5.7-fold increase in STAT3 phosphorylation (Figure $6 \mathrm{~B}, P=0.0084$ ) and led to a 2.1fold increase in expression of the endogenous, STAT3dependent $S O C S 3$ gene (Figure $6 \mathrm{C}, P=0.001$ ). These data show that CHO-K1 cells co-expressing STAT3 and the bovine $\mathrm{Ob}-\mathrm{Rb}$ are a valid system to assess the ability of ORM1 to signal through Ob-Rb.

Finally, we asked whether ORM1 can induce STAT3 signaling in CHO-K1 cells co-overexpressing STAT3 and Ob-Rb. Cells were incubated for 15 min with either 100 $\mathrm{ng} / \mathrm{mL}$ of bovine leptin or $100 \mu \mathrm{g} / \mathrm{mL}$ of bovine ORM1. As shown in Figure 7A, bovine leptin caused a 5.9fold increase in STAT3 phosphorylation $(P=0.006)$, whereas bovine ORM1 was completely ineffective. We considered the possibility that ORM1 activation of the $\mathrm{Ob}-\mathrm{Rb}$ required a longer incubation period or higher ORM1 concentrations. Cells were treated with $100 \mathrm{ng} /$ $\mathrm{mL}$ of bovine leptin or $100 \mu \mathrm{g} / \mathrm{mL}$ of bovine ORM1 for 0 to $12 \mathrm{~h}$ (Figure 7B). Bovine leptin increased STAT3 phosphorylation for the first $3 \mathrm{~h}$, whereas bovine ORM1 was ineffective at all incubation times. Incubation with up to $1,000 \mu \mathrm{g} / \mathrm{mL}$ of bovine ORM1 for either $15 \mathrm{~min}$ or $7 \mathrm{~h}$ was also ineffective in stimulating STAT3 phosphorylation (Figure 7C).

We also considered the possibility that ORM1 potentiates the ability of leptin to induce $\mathrm{Ob}-\mathrm{Rb}$ signaling (Figure 8A). The CHO-K1 co-overexpressing STAT3 
and bovine $\mathrm{Ob}-\mathrm{Rb}$ were incubated with bovine leptin and ORM1 alone or together for 15 min (ORM1 coincubation) or alternatively incubated with ORM1 for $7 \mathrm{~h}$ and then stimulated for $15 \mathrm{~min}$ with bovine leptin (ORM1 pre-incubation). Neither ORM1 combination led to potentiation of leptin-dependent STAT3 phos-

A

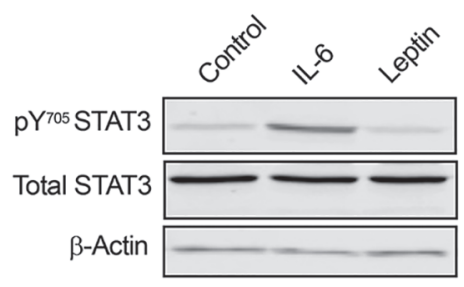

B
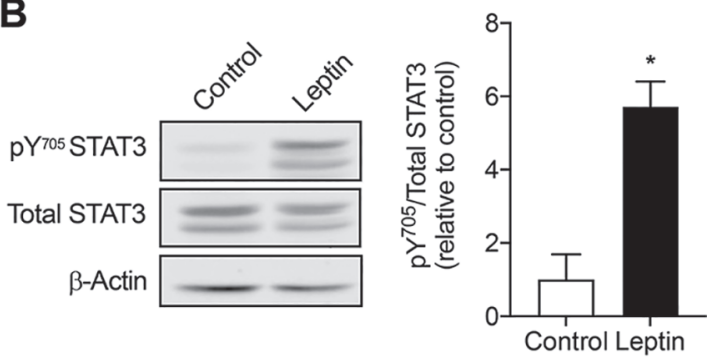

C

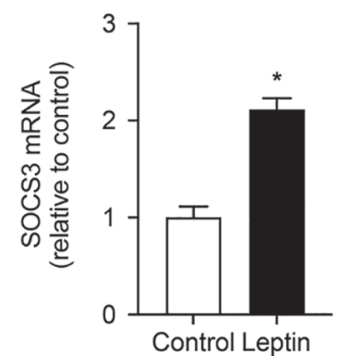

Figure 6. The bovine leptin receptor confers leptin responsiveness to Chinese hamster ovary K1 (CHO-K1) cells. The CHO-K cells were transfected with an expression plasmid encoding signal transducer and activator of transcription 3 (pRc/CMV-STAT3) alone or in the presence of an expression plasmid encoding the bovine leptin receptor (pcDNA-bLEPR). Transfected cells were incubated overnight in serum-free medium followed by hormone treatment. Protein extracts $(25$ $\mu \mathrm{g}$ ) were analyzed by western immunoblotting for the abundance of STAT3 phosphorylated on tyrosine 705 ( $\mathrm{pY}^{705}$ STAT3), total STAT3, and $\beta$-actin. (A) $\mathrm{CHO}-\mathrm{K}$ cells transfected with expression plasmid pRc/CMV-STAT3 were incubated for $15 \mathrm{~min}$ in the absence (Control) or presence of rat interleukin 6 (IL-6, $100 \mathrm{ng} / \mathrm{mL}$ ) or bovine leptin (100 $\mathrm{ng} / \mathrm{mL}$ ). Data shown are representative of 3 experiments. (B) CHO-K cells transfected with expression plasmids pRc/CMV-STAT3 and pcDNA-bLEPR were incubated for $15 \mathrm{~min}$ in the absence (Control) or presence of bovine leptin $(100 \mathrm{ng} / \mathrm{mL})$. Left: representative Western blot image of $\mathrm{pY}^{705}$ STAT3, total STAT3, and $\beta$-actin. Right: STAT3 phosphorylation was calculated as the ratio of $\mathrm{pY}^{705}$ STAT3 to total STAT3. The ratio is expressed relative to control cells with each bar representing the $\mathrm{LSM} \pm \mathrm{SE}$ of 3 replicates. ${ }^{*} P=0.0084$. (C) $\mathrm{CHO}-\mathrm{K}$ cells transfected with expression plasmids pCMV-STAT3 and pcDNAbLEPR and were incubated in the absence (Control) or presence of bovine leptin $(100 \mathrm{ng} / \mathrm{mL})$ for $6 \mathrm{~h}$. Total RNA was isolated and analyzed for suppressor of cytokine signaling 3 (SOCS3) mRNA abundance. Each bar represents the LSM $\pm \mathrm{SE}$ of 4 replicates. ${ }^{*} P=0.001$. phorylation. Finally, we replaced bovine with human ORM1 on the basis of its use in the original report of ORM1 activation of STAT3 via mouse Ob-Rb (Sun et al., 2016); incubation with $1,000 \mu \mathrm{g} / \mathrm{mL}$ of human ORM1 for either $15 \mathrm{~min}$ or $7 \mathrm{~h}$ was similarly ineffective in inducing STAT3 phosphorylation (Figure 8B). Overall, these results show that ORM1 is unable to activate STAT3 via Ob-Rb.

\section{DISCUSSION}

Orosomucoid 1, HP, SAA, LBP, and C-reactive protein belong to a group of structurally unrelated proteins known as APP (Ceciliani et al., 2012; Eckel and Ametaj, 2016). This name stems from their rapid increase in plasma following entry of endotoxins and other toxic substrates into the vascular system. In the liver, endotoxins stimulate Kupffer cell production of inflammatory cytokines, which in turn trigger the synthesis of APP in hepatocytes (Ceciliani et al., 2012; Eckel and Ametaj, 2016). Functionally, APP contribute to the resolution of inflammatory insults through their ability to sequester small molecules and to regulate a variety of innate immune functions (Ceciliani et al., 2012). For example, ORM1 was shown to bind LPS in a mouse model of endotoxemia (McCurdy et al., 2014) and to upregulate tumor necrosis factor $\alpha$ production in human monocytes ( $\mathrm{Su}$ and Yeh, 1996). A notable recent development regarding ORM1 was its identification as a regulator of voluntary feed intake in the mouse. Specifically, peripheral administration of human ORM1 reduced feed intake in wildtype and $o b / o b$ mice and caused increased hypothalamic STAT3 phosphorylation; these effects were completely absent in $d b / d b$ mice lacking the functional Ob-Rb (Sun et al., 2016). The ability of human ORM1 to trigger Ob-Rb signaling was corroborated in the mouse hypothalamic cell line GT1-7 and supported by modeling of the X-ray crystal structures of human ORM1 and mouse Ob-Rb (Sun et al., 2016). Overall, these data suggested a model whereby ORM1 represses voluntary feed intake by activating Ob-Rb-dependent-STAT3 signaling. If bovine ORM1 functions similarly, it could contribute to the inadequate appetite seen in lactation with conditions associated with increased inflammatory tone.

Most studies on ORM1 in cattle have been performed in the context of infectious diseases (Eckersall et al., 2001; Sheldon et al., 2001). We first assessed the regulation of plasma ORM1 during the transition period when appetite is insufficient. Others have reported increased plasma HP at parturition in disease-free cows followed by a return to pre-calving levels over the next 8 to 10 d (Bossaert et al., 2012; Saremi et al., 2012; Trevisi and Minuti, 2018). Our data showed that the 
A

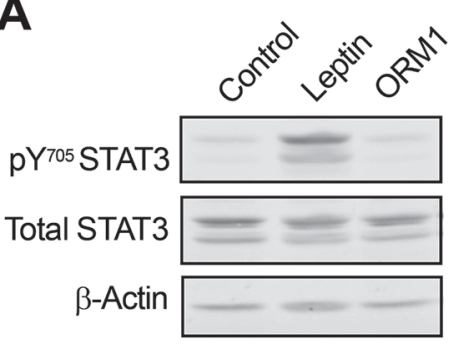

B

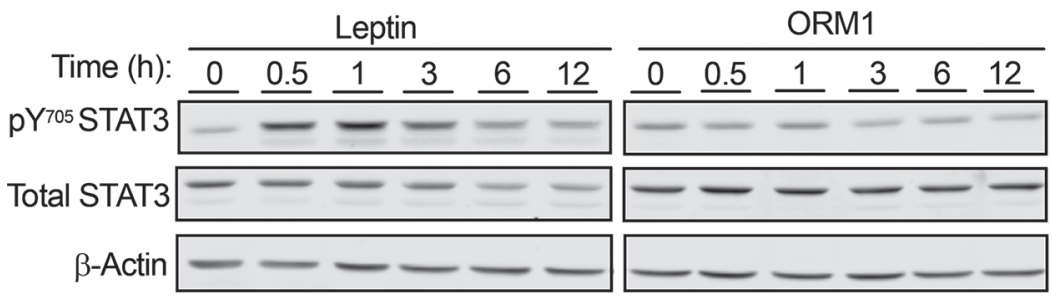

C

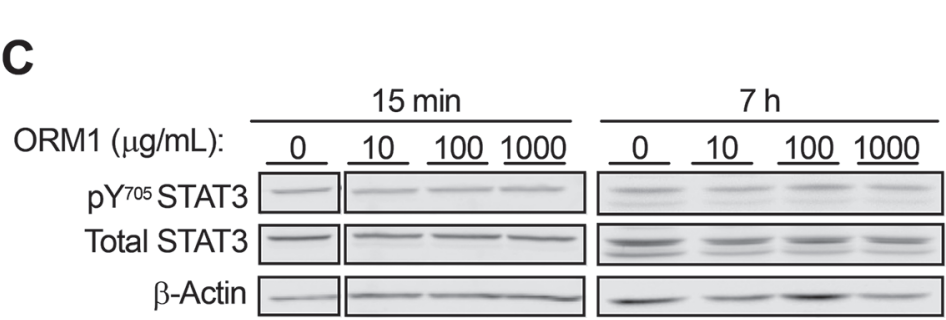

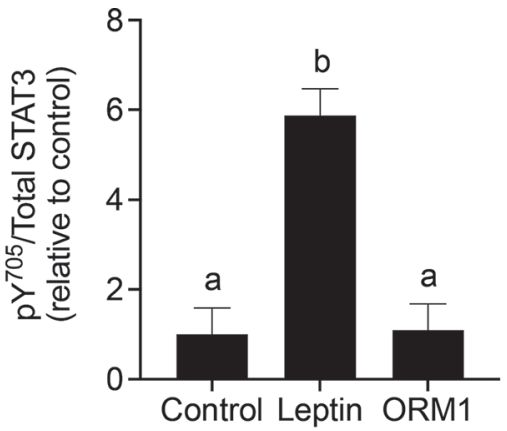

Control Leptin ORM1

Figure 7. Bovine orosomucoid 1 (ORM1) does not activate STAT3 in Chinese hamster ovary K1 (CHO-K1) cells expressing the bovine leptin receptor. The CHO-K cells were transfected with expression plasmids encoding signal transducer and activator of transcription 3 (pCMVSTAT3) and the bovine leptin receptor (pcDNA-bLEPR). Transfected cells were kept overnight in serum-free medium followed by treatment. Protein extracts $\left(25 \mu \mathrm{g}\right.$ ) were analyzed by Western immunoblotting for the abundance of STAT3 phosphorylated on tyrosine 705 (pY ${ }^{705}$ STAT3), total STAT3, and $\beta$-actin. (A) Left: cells were incubated for $15 \mathrm{~min}$ in the absence (Control) or presence of bovine leptin (100 ng/mL) or bovine ORM1 $(100 \mu \mathrm{g} / \mathrm{mL})$. Right: STAT3 phosphorylation was calculated as the ratio of $\mathrm{pY}^{705}$ STAT3 to total STAT3. The ratio is expressed relative to control cells with each bar representing the LSM $\pm \mathrm{SE}$ of 3 replicates. Bars with different letters are significantly different at $P=0.006$. (B) Cells were incubated for the indicated times in the absence or presence of bovine leptin $(100 \mathrm{ng} / \mathrm{mL})$ or bovine ORM1 $(100 \mu \mathrm{g} / \mathrm{mL})$. (C) Cells were incubated with indicated concentrations of bovine ORM1 for either $15 \mathrm{~min}$ or $7 \mathrm{~h}$. The lane corresponding to $0 \mu \mathrm{g} / \mathrm{mL}$ ORM 1 for the 15 min incubation is shown as segregated because it was not continuous to the other lanes.

profile of plasma ORM1 rises steadily over the first $7 \mathrm{~d}$ of lactation to a concentration that is 2.5 -fold greater than that of LP and then remains at this plateau level at least until d 21 of lactation, confirming earlier work (Cairoli et al., 2006; Jafari et al., 2006). More importantly, plasma ORM1 was positively related to hepatic ORM1 mRNA during the transition period when hepatic ORM1 mRNA nearly doubled between LP and EL. In contrast, ORM1 expression remained invariant throughout the transition period in adipose tissue and mammary gland. Finally, in agreement with Lecchi et al. (2009), we showed that ORM1 expression in liver is many fold higher than that of adipose tissue, mammary gland, and other tissues we surveyed. Collectively, these data support liver as the major driver of increased plasma ORM1 during the transition from LP to EL and are consistent with the possibility that increased ORM1 contributes to inadequate appetite after parturition.

Plasma APP are often increased during conditions causing suboptimal voluntary feed intake in lactating dairy cows, reflecting vascular endotoxin entry (Baumgard and Rhoads, 2013; Eckel and Ametaj, 2016). Accordingly, we used 3 small studies performed under carefully controlled conditions to examine ORM1 regulation when reduced appetite coincided with increased plasma concentrations of other APP. Specifically, we reported a $39 \%$ elevation in plasma HP on d 3 of lactation in cows with impaired ovarian function (Cheong et al., 2017), whereas plasma LBP and SAA were increased 2.5- and 5 -fold during a heat-stress period. We also documented that excessively fat cows experienced a 2.3-fold increase in liver lipid on d 4 of lactation (fat vs. lean cows, 14 vs. 6\%; Saed Samii et al., 2019), a condition previously 
shown to increase plasma HP and SAA (Ametaj et al., 2005). Plasma ORM1, however, was not upregulated under any of these conditions, indicating that it plays no role in the associated reduction of appetite. In addition, these experiments suggested that ORM1 regulation differs from that of other APP. This possibility was confirmed by absence of ORM1 regulation during the 16-h period following an LPS challenge despite strong upregulation of indices of SAA and HP production, whether plasma ORM1 increases at later times after endotoxin challenge remains unknown. A somewhat similar discrepancy has also been demonstrated in the pig where LPS increased HP but had the opposite effect on ORM1 (Heegaard et al., 2013).

Finally, we tested whether ORM1 could activate bovine Ob-Rb signaling using CHO-K1 cells and STAT3 phosphorylation as a reporter of receptor activation. Similar systems have been used to resolve various aspects of leptin signaling including the critical AA residues involved in the formation of functional $\mathrm{Ob}-$ $\mathrm{Rb}$ complexes with leptin and to identify signaling pathways (Bjørbæk et al., 1997; Biener et al., 2005; Niv-Spector et al., 2005). Using these systems, STAT3 was identified as a major leptin signaling protein and tyrosine residue 1138 in $\mathrm{Ob}-\mathrm{Rb}$ as essential to STAT3 phosphorylation (Baumann et al., 1996; Banks et al., 2000; Bjørbæk et al., 2000). Subsequent in vivo studies showed that STAT3 signaling was necessary and sufficient for the appetite repressing effects of Ob-Rb (Bates et al., 2003; Pan et al., 2019). Importantly, we showed that CHO-K1 cells are devoid of any expression of the endogenous $\mathrm{Ob}-\mathrm{Rb}$ gene, and consequently, incapable of leptin-induced signaling unless transfected with bovine Ob-Rb. The transfected CHO-K1 cells expressing Ob-
$\mathrm{Rb}$ then responded to leptin with a 5.7-fold increase in STAT3 phosphorylation and a 2.1-fold induction of the endogenous STAT3-dependent gene, SOCS3. Using this system, we showed that bovine ORM1 is incapable of triggering STAT3 phosphorylation irrespective of concentration and period of incubation tested, including the exact conditions used by Sun et al. (2016). These authors used human ORM1 in their studies raising the possibility that human ORM1 is unique in its ability to interact with Ob-Rb. Human ORM1, however, was also completely ineffective in activating STAT3 in CHO-K1 cells expressing bovine Ob-Rb. Accordingly, we conclude that bovine ORM1 is incapable of Ob-Rbdependent STAT3 signaling, ruling out the involvement of this pathway in mediating ORM1 action on appetite in dairy cattle.

Evidence is growing that vascular entry of endotoxins contributes to the suboptimal appetite seen in EL and during various diseases and environmental insults (Baumgard and Rhoads, 2013). However, scenarios where endotoxins and their inflammatory mediators reduce voluntary feed intake via direct interactions with $\mathrm{Ob}-\mathrm{Rb}$ are incongruent with existing leptin work in ruminants. Specifically, a suppressive effect on appetite has never been shown in ruminants when leptin is administered peripherally (Morrison et al., 2002; Ehrhardt et al., 2016). This effect is seen only with intra-cerebroventricular administration exposing neuronal centers to leptin concentration 2 to 3 orders of magnitude over physiological concentrations (Henry et al., 1999; Foskolos et al., 2015), and even this intracerebroventricular effect disappears when a state of chronic energy insufficiency prevails (Henry et al., 2001; Morrison et al., 2001). Because leptin does not suppress
A

\section{ORM1 co-incubation}

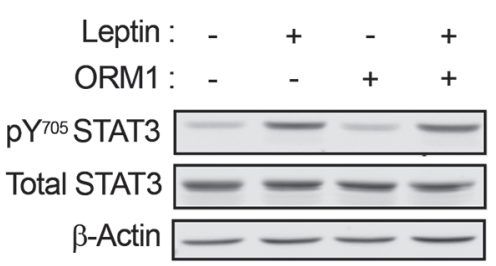

ORM1 pre-incubation

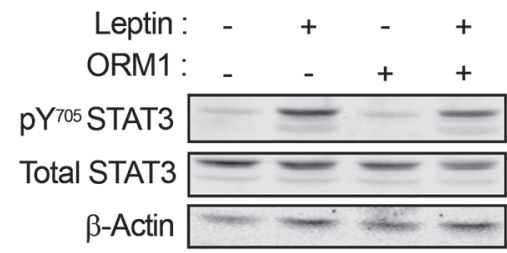

B

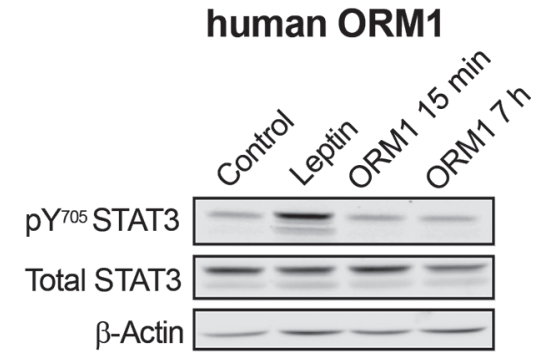

Figure 8. Orosomucoid 1 (ORM1) does not potentiate leptin signaling in Chinese hamster ovary K1 (CHO-K1) cells expressing the bovine leptin receptor. The CHO-K cells were transfected with expression plasmids encoding signal transducer and activator of transcription 3 (pRc/ CMV-STAT3) and the bovine leptin receptor (pcDNA-bLEPR). Transfected cells were kept overnight in serum-free medium followed by treatment. Protein extracts $\left(25 \mu \mathrm{g}\right.$ ) were analyzed by Western immunoblotting for the abundance of STAT3 phosphorylated on tyrosine 705 (pY ${ }^{705}$ STAT3), total STAT3, and $\beta$-actin. (A) Cells were incubated in the absence (-) or presence (+) of $100 \mathrm{ng} / \mathrm{mL}$ of bovine leptin and $1,000 \mu \mathrm{g} / \mathrm{mL}$ of bovine ORM1 (ORM1 co-incubation) or pre-incubated in the absence (-) or presence $(+)$ of $1,000 \mu \mathrm{g} / \mathrm{mL}$ of bovine ORM1 for $7 \mathrm{~h}$ followed by a 15-min period of treatment with $100 \mathrm{ng} / \mathrm{mL}$ of bovine leptin (ORM1 pre-incubation). (B) Cells were incubated in the absence (Control) or presence of bovine leptin (Leptin, $100 \mathrm{ng} / \mathrm{mL}$ ) for $15 \mathrm{~min}$ or human ORM1 (1,000 $\mu \mathrm{g} / \mathrm{mL}$ ) for either $15 \mathrm{~min}$ (ORM1 $15 \mathrm{~min})$ or $7 \mathrm{~h}$ (ORM1 $7 \mathrm{~h}$ ). 
appetite under physiological conditions in ruminants, it is very unlikely that non-cognate inflammatory proteins reduce appetite by coopting $\mathrm{Ob}-\mathrm{Rb}$ function.

In summary, we showed that plasma ORM1 increases dynamically in the postparturient period but is unaffected in other conditions where suboptimal appetite occurs in association with increased plasma concentration of other APP. Bovine ORM1 is also incapable of triggering Ob-Rb-dependent STAT3 signaling, and accordingly, this signaling axis cannot mediate any ORM1 effect in dairy cattle.

\section{ACKNOWLEDGMENTS}

This material is based upon work supported by the National Institute of Food and Agriculture, U.S. Department of Agriculture (Washington, DC) under grant numbers 2017-05931 awarded to L.H.B, 2007-3520318420 awarded to W.R.B, 2014-67016-21611 and 201667015-24582 awarded to J.W.M., by Hatch/Multistate projects under 1017053 awarded to Y.R.B., and by Vetagro S.p.A. (Reggio Emilia, Italy) awarded to J.W.M. The authors have not stated any conflicts of interest.

\section{REFERENCES}

Al-Qaisi, M., E. A. Horst, S. K. Kvidera, E. J. Mayorga, L. L. Timms, and L. H. Baumgard. 2019. Technical note: Developing a heat stress model in dairy cows using an electric heat blanket. J. Dairy Sci. 102:684-689. https://doi.org/10.3168/jds.2018-15128.

Ametaj, B. N., B. J. Bradford, G. Bobe, R. A. Nafikov, Y. Lu, J. W. Young, and D. C. Beitz. 2005. Strong relationships between mediators of the acute phase response and fatty liver in dairy cows. Can. J. Anim. Sci. 85:165-175. https://doi.org/10.4141/A04-043.

Banks, A. S., S. M. Davis, S. H. Bates, and M. G. Myers Jr.. 2000. Activation of downstream signals by the long form of the leptin receptor. J. Biol. Chem. 275:14563-14572. https://doi.org/10.1074/ jbc.275.19.14563.

Bates, S. H., W. H. Stearns, T. A. Dundon, M. Schubert, A. W. K. Tso, Y. Wang, A. S. Banks, H. J. Lavery, A. K. Haq, E. MaratosFlier, B. G. Neel, M. W. Schwartz, and M. G. Myers. 2003. STAT3 signalling is required for leptin regulation of energy balance but not reproduction. Nature 421:856-859. https://doi.org/10.1038/ nature01388.

Baumann, H., K. K. Morella, D. W. White, M. Dembski, P. S. Bailon, H. Kim, C. F. Lai, and L. A. Tartaglia. 1996. The full-length leptin receptor has signaling capabilities of interleukin 6-type cytokine receptors. Proc. Natl. Acad. Sci. USA 93:8374-8378. https://doi .org/10.1073/pnas.93.16.8374.

Baumgard, L. H., and R. P. Rhoads Jr.. 2013. Effects of heat stress on postabsorptive metabolism and energetics. Annu. Rev. Anim. Biosci. 1:311-337. https://doi.org/10.1146/annurev-animal-031412 -103644 .

Biener, E., M. Charlier, V. K. Ramanujan, N. Daniel, A. Eisenberg, C. Bjørbaek, B. Herman, A. Gertler, and J. Djiane. 2005. Quantitative FRET imaging of leptin receptor oligomerization kinetics in single cells. Biol. Cell 97:905-919. https://doi.org/10.1042/ BC20040511.

Bjørbæk, C., H. J. Lavery, S. H. Bates, R. K. Olson, S. M. Davis, J. S. Flier, and M. G. Myers Jr.. 2000. SOCS3 mediates feedback inhibition of the leptin receptor via Tyr985. J. Biol. Chem. 275:4064940657. https://doi.org/10.1074/jbc.M007577200.
Bjørbæk, C., S. Uotani, B. da Silva, and J. S. Flier. 1997. Divergent signaling capacities of the long and short isoforms of the leptin receptor. J. Biol. Chem. 272:32686-32695. https://doi.org/10.1074/ jbc.272.51.32686.

Bossaert, P., E. Trevisi, G. Opsomer, G. Bertoni, S. De Vliegher, and J. L. M. R. Leroy. 2012. The association between indicators of inflammation and liver variables during the transition period in high-yielding dairy cows: An observational study. Vet. J. 192:222225. https://doi.org/10.1016/j.tvj1.2011.06.004.

Cairoli, F., M. Battocchio, M. C. Veronesi, D. Brambilla, F. Conserva, I. Eberini, R. Wait, and E. Gianazza. 2006. Serum protein pattern during cow pregnancy: Acute-phase proteins increase in the peripartum period. Electrophoresis 27:1617-1625. https://doi.org/ 10.1002/elps.200500742.

Ceciliani, F., J. J. Ceron, P. D. Eckersall, and H. Sauerwein. 2012. Acute phase proteins in ruminants. J. Proteomics 75:4207-4231. https://doi.org/10.1016/j.jprot.2012.04.004.

Cheong, S. H., O. G. S. Filho, V. A. Absalón-Medina, S. H. Pelton, W. R. Butler, and R. O. Gilbert. 2016. Metabolic and endocrine differences between dairy cows that do or do not ovulate first postpartum dominant follicles. Biol. Reprod. 94. https://doi.org/ 10.1095/biolreprod.114.127076.

Cheong, S. H., O. G. Sá Filho, V. A. Absalon-Medina, A. Schneider, W. R. Butler, and R. O. Gilbert. 2017. Uterine and systemic inflammation influences ovarian follicular function in postpartum dairy cows. PLoS One 12:e0177356. https://doi.org/10.1371/ journal.pone.0177356.

Dantzer, R., J. C. O'Connor, G. G. Freund, R. W. Johnson, and K. W. Kelley. 2008. From inflammation to sickness and depression: When the immune system subjugates the brain. Nat. Rev. Neurosci. 9:46-56. https://doi.org/10.1038/nrn2297.

Davis, A. N., J. E. Rico, W. A. Myers, M. J. Coleman, M. E. Clapham, N. J. Haughey, and J. W. McFadden. 2019. Circulating lowdensity lipoprotein ceramide concentrations increase in Holstein dairy cows transitioning from gestation to lactation. J. Dairy Sci. 102:5634-5646. https://doi.org/10.3168/jds.2018-15850.

Drackley, J. K. 1999. Biology of dairy cows during the transition period: The final frontier? J. Dairy Sci. 82:2259-2273. https://doi .org/10.3168/jds.S0022-0302(99)75474-3.

Eckel, E. F., and B. N. Ametaj. 2016. Invited review: Role of bacterial endotoxins in the etiopathogenesis of periparturient diseases of transition dairy cows. J. Dairy Sci. 99:5967-5990. https://doi.org/ 10.3168/jds.2015-10727.

Eckersall, P. D., F. J. Young, C. McComb, C. J. Hogarth, S. Safi, A. Weber, T. McDonald, A. M. Nolan, and J. L. Fitzpatrick. 2001. Acute phase proteins in serum and milk from dairy cows with clinical mastitis. Vet. Rec. 148:35-41. https://doi.org/10.1136/vr .148 .2 .35 .

Ehrhardt, R. A., A. Foskolos, S. L. Giesy, S. R. Wesolowski, C. S. Krumm, W. R. Butler, S. M. Quirk, M. R. Waldron, and Y. R. Boisclair. 2016. Increased plasma leptin attenuates adaptive metabolism in early lactating dairy cows. J. Endocrinol. 229:145-157. https://doi.org/10.1530/JOE-16-0031.

Foskolos, A., R. A. Ehrhardt, S. M. Hileman, A. Gertler, and Y. R. Boisclair. 2015. Insensitivity of well-conditioned mature sheep to central administration of a leptin receptor antagonist. Animal 9:1852-1858. https://doi.org/10.1017/S1751731115001159.

Heegaard, P. M. H., I. Miller, N. S. Sorensen, K. E. Soerensen, and K. Skovgaard. 2013. Pig $\alpha_{1}$-acid glycoprotein: Characterization and first description in any species as a negative acute phase protein. PLoS One 8:e68110. https://doi.org/10.1371/journal.pone .0068110 .

Henry, B. A., J. W. Goding, W. S. Alexander, A. J. Tilbrook, B. J. Canny, F. Dunshea, A. Rao, A. Mansell, and I. J. Clarke. 1999. Central administration of leptin to ovariectomized ewes inhibits food intake without affecting the secretion of hormones from the pituitary gland: Evidence for a dissociation of effects on appetite and neuroendocrine function. Endocrinology 140:1175-1182. https: //doi.org/10.1210/endo.140.3.6604.

Henry, B. A., J. W. Goding, A. J. Tilbrook, F. R. Dunshea, and I. J. Clarke. 2001. Intracerebroventricular infusion of leptin elevates 
the secretion of luteinising hormone without affecting food intake in long-term food-restricted sheep, but increases growth hormone irrespective of bodyweight. J. Endocrinol. 168:67-77. https://doi .org/10.1677/joe.0.1680067.

Horst, E. A., L. M. van den Brink, E. J. Mayorga, M. Al-Qaisi, S. Rodriguez-Jimenez, B. M. Goetz, M. A. Abeyta, and L. H. Baumgard. 2019. Effects of intralipid infusion on metabolism and inflammation in immune-challenged lactating cows. J. Dairy Sci. 102(E-Suppl. 1):214. (Abstr.)

Jafari, A., D. G. V. Emmanuel, R. J. Christopherson, J. R. Thompson, G. K. Murdoch, J. Woodward, C. J. Field, and B. N. Ametaj. 2006 Parenteral administration of glutamine modulates acute phase response in postparturient dairy cows. J. Dairy Sci. 89:4660-4668. https://doi.org/10.3168/jds.S0022-0302(06)72516-4.

Kvidera, S. K., M. J. Dickson, M. Abuajamieh, D. B. Snider, M. V. S. Fernandez, J. S. Johnson, A. F. Keating, P. J. Gorden, H. B. Green, K. M. Schoenberg, and L. H. Baumgard. 2017. Intentionally induced intestinal barrier dysfunction causes inflammation, affects metabolism, and reduces productivity in lactating Holstein cows. J. Dairy Sci. 100:4113-4127. https://doi.org/10.3168/jds 2016-12349.

Lecchi, C., G. Avallone, M. Giurovich, P. Roccabianca, and F. Ceciliani. 2009. Extra hepatic expression of the acute phase protein alpha 1-acid glycoprotein in normal bovine tissues. Vet. J. 180:256258. https://doi.org/10.1016/j.tvjl.2007.12.027.

McCurdy, T. R., A. L. Patrick, L. J. Eltringham-Smith, V. Bhakta, W. P. Sheffield, and A. E. Fox-Robichaud. 2014. Alpha-1 acid glycoprotein reduces hepatic leukocyte recruitment in murine models of either early endotoxemia or early sepsis. Microcirculation 21:74-83. https://doi.org/10.1111/micc.12081.

Morrison, C. D., J. A. Daniel, B. J. Holmberg, J. Djiane, N. Raver, A. Gertler, and D. H. Keisler. 2001. Central infusion of leptin into well-fed and undernourished ewe lambs: effects on feed intake and serum concentrations of growth hormone and luteinizing hormone. J. Endocrinol. 168:317-324. https://doi.org/10.1677/joe.0 .1680317 .

Morrison, C. D., R. Wood, E. L. McFadin, N. C. Whitley, and D. H. Keisler. 2002. Effect of intravenous infusion of recombinant ovine leptin on feed intake and serum concentrations of GH, LH, insulin, IGF-1, cortisol, and thyroxine in growing prepubertal ewe lambs. Domest. Anim. Endocrinol. 22:103-112. https://doi.org/10.1016/ S0739-7240(01)00129-1.

Niv-Spector, L., D. Gonen-Berger, I. Gourdou, E. Biener, E. E. Gussakovsky, Y. Benomar, K. V. Ramanujan, M. Taouis, B. Herman, I. Callebaut, J. Djiane, and A. Gertler. 2005. Identification of the hydrophobic strand in the A-B loop of leptin as major binding site III: Implications for large-scale preparation of potent recombinant human and ovine leptin antagonists. Biochem. J. 391:221-230. https://doi.org/10.1042/BJ20050457.

Pan, W., M. B. Allison, P. Sabatini, A. Rupp, J. Adams, C. Patterson, J. C. Jones, D. P. Olson, and M. G. Myers Jr.. 2019. Transcriptional and physiological roles for STAT proteins in leptin action. Mol. Metab. 22:121-131. https://doi.org/10.1016/j.molmet.2019 .01 .007 .
Roche, J. R., A. W. Bell, T. R. Overton, and J. J. Loor. 2013. Nutritional management of the transition cow in the 21st century - A paradigm shift in thinking. Anim. Prod. Sci. 53:1000-1023. https: //doi.org/10.1071/AN12293.

Saed Samii, S., J. E. Rico, A. T. Mathews, A. N. Davis, C. L. Orndorff, L. O. Aromeh, and J. W. McFadden. 2019. Effects of body condition score on direct and indirect measurements of insulin sensitivity in periparturient dairy cows. Animal 13:2547-2555. https: //doi.org/10.1017/S175173111900065X.

Saremi, B., A. Al-Dawood, S. Winand, U. Müller, J. Pappritz, D. von Soosten, J. Rehage, S. Dänicke, S. Häussler, M. Mielenz, and H. Sauerwein. 2012. Bovine haptoglobin as an adipokine: Serum concentrations and tissue expression in dairy cows receiving a conjugated linoleic acids supplement throughout lactation. Vet. Immunol. Immunopathol. 146:201-211. https://doi.org/10.1016/j .vetimm.2012.03.011.

Sheldon, I. M., D. E. Noakes, A. Rycroft, and H. Dobson. 2001. Acute phase protein responses to uterine bacterial contamination in cattle after calving. Vet. Rec. 148:172-175. https://doi.org/10.1136/ vr.148.6.172.

Soberon, F., C. M. Ryan, D. V. Nydam, D. M. Galton, and T. R. Overton. 2011. The effects of increased milking frequency during early lactation on milk yield and milk composition on commercial dairy farms. J. Dairy Sci. 94:4398-4405. https://doi.org/10.3168/ jds. 2010-3640.

Su, S. J., and T. M. Yeh. 1996. Effects of alpha 1-acid glycoprotein on tissue factor expression and tumor necrosis factor secretion in human monocytes. Immunopharmacology 34:139-145. https://doi .org/10.1016/0162-3109(96)00137-3.

Sun, Y., Y. Yang, Z. Qin, J. Cai, X. Guo, Y. Tang, J. Wan, D.-F. Su, and X. Liu. 2016. The acute-phase protein orosomucoid regulates food intake and energy homeostasis via leptin receptor signaling pathway. Diabetes 65:1630-1641. https://doi.org/10.2337/db15 $-1193$.

Thorn, S. R., M. J. Meyer, M. E. Van Amburgh, and Y. R. Boisclair. 2007. Effect of estrogen on leptin and expression of leptin receptor transcripts in prepubertal dairy heifers. J. Dairy Sci. 90:37423750. https://doi.org/10.3168/jds.2007-0009.

Trevisi, E., and A. Minuti. 2018. Assessment of the innate immune response in the periparturient cow. Res. Vet. Sci. 116:47-54. https: //doi.org/10.1016/j.rvsc.2017.12.001.

Zang, Y., S. Saed Samii, W. A. Myers, H. R. Bailey, A. N. Davis, E. Grilli, and J. W. McFadden. 2019. Methyl donor supplementation suppresses the progression of liver lipid accumulation while modifying the plasma triacylglycerol lipidome in periparturient Holstein dairy cows. J. Dairy Sci. 102:1224-1236. https://doi.org/10.3168/ jds.2018-14727.

Zhong, Z., Z. Wen, and J. E. Darnell. 1994. Stat3 and Stat4: Members of the family of signal transducers and activators of transcription. Proc. Natl. Acad. Sci. USA 91:4806-4810. https://doi.org/10 $.1073 /$ pnas.91.11.4806 